\title{
PEMBERIAN TERAPI HYPNO PRENATAL DAN PRENATAL MASSAGE PADA IBU HAMIL DIMASA PANDEMI COVID-19
}

\author{
Yulia Arifin', Ety Aprianti²
}

1Prodi Kebidanan Program Sarjana dan Pendidikan Profesi Bidan Program Profesi, STIKes MERCUBAKTIJAYA Padang

${ }^{2}$ Prodi DIII Kebidanan, STIKes MERCUBAKTIJAYA Padang

E-mail korespondensi: youlee24@gmail.com ${ }^{1}$

\begin{tabular}{l} 
Article History: \\
\hline Received: 7-12-2021 \\
Revised: 8-12-2021 \\
Accepted: 16-12-2021 \\
\\
Kata Kunci : Hypno \\
prenatal, Prenatal \\
Massage, Kecemasan
\end{tabular}

Article History:

Revised: 8-12-2021

Accepted: 16-12-2021

\begin{abstract}
Abstrak:
Latar Belakang: Kecemasan pada ibu hamil dapat dipengaruhi karena tidak melakukan pemeriksaan ANC. Pemeriksaan ANC yang dilakukan oleh ibu dapat membantu mengendalikan rasa cemas yang muncul saat kehamilannya, salah satu upaya yang dilakukan tenaga kesehatan untuk menurunkan angka kecemasan pada ibu hamil. Ibu hamil tercatat salah satu kelompok rentan resiko terinfeksi COVID19 dikarenakan pada masa kehamilan terjadinya perubahan fisiologi yang mengakibatkan penurunan kekebalan parsial. Dengan kondisi kesehatan dunia sekarang ini yang sedang dilanda pandemi COVID-19, membuat ibu semakin cemas dengan keadaan lingkungannya. Untuk mengurangi rasa cemas ibu dapat diatasi dengan terapi Hypno prenatal dan prenatal message. Hypno prenatal merupakan suatu kegiatan yang dapat membantu seseorang menjadi rileks dan tenang, dimana efek dari kondisi ini akan berpengaruh terhadap ibu dan lingkungannya. Sedangkan prenatal massage diketahui dapat meningkatkan relaksasi, mengurangi nyeri dan stres, dan sangat banyak manfaat kesehatannya pada ibu hamil.

Metode Pelaksanaan: Pengabdian masyarakat ini dilakukan di Klinik MERCUBAKTIJAYA Padang dengan mekanisme pelaksanaan pemeriksaan Antenatal Care, penyuluhan, pemberian terapi hypno prenatal dan prenatal message kepada ibu hamil. Kegiatan ini dilakukan pada Tanggal 16 Desember 2020.

Hasil: dari pelaksanaan kegiatan pengabdian masyarakat ini adalah $100 \%$ kondisi kehamilan ibu hamil dalam keadaan baik dan sehat, $100 \%$ ibu hamil dapat memahami dan mengerti tentang hypno prenatal dan prenatal massage dan $100 \%$ ibu mengalami penurunan rasa cemas pada ibu hamil.
\end{abstract}


Keywords: Hypno prenatal, Prenatal Massage, Anxiety

\begin{abstract}
Background: Anxiety in pregnant women can be affected because they do not perform ANC examinations. ANC examinations carried out by mothers can help control the anxiety that arises during pregnancy, one of the efforts made by health workers to reduce anxiety rates in pregnant women. Pregnant women are listed as one of the vulnerable groups at risk of being infected with COVID-19 because during pregnancy there are physiological changes that result in a partial decrease in immunity. With the current world health condition that is being hit by the COVID-19 pandemic, mothers are increasingly worried about the state of their environment. To reduce maternal anxiety, it can be overcome with hypno prenatal and prenatal messages for pregnant women. Hypno prenatal is an activity that can help a person relax and calm, where the effects of this condition will affect the mother and the environment. prenatal massage is known to increase relaxation, reduce pain and stress, and has many health benefits for pregnant women.

Methods: This community service was carried out at the MERCUBAKTIJAYA Clinic in Padang with the mechanism of carrying out Antenatalcare examinations, counseling, giving hypno prenatal and prenatal message to pregnant women. This activity was carried out on December 16, 2020.

Results: of the implementation of this community service activity are that $100 \%$ of pregnant women are in good and healthy condition, $100 \%$ of pregnant women can understand and understand about hypnobirthing and prenatal massage and 100\% of mothers decreased anxiety in pregnant women.
\end{abstract}

\section{Pendahuluan}

Kehamilan adalah suatu proses fisiologis yang terjadi pada perempuan akibat adanya pembuahan antara sel kelamin laki-laki dan sel kelamin perempuan,atau dapat pula sebagai pembuahan ovum oleh spermatozoa sehingga mengalami nidasi pada uterus dan berkembang sampai kelahiran janin. Selama kehamilan perlu dilakukannya pemeriksaan kehamilan (antenatal care) sebanyak 6 kali, dimana setiap pemeriksaan dilakukan pada Trimester 1 sebanyak 2 kali, Trimester 2 sebanyak 1 kali, dan Trimester 3 sebanyak 3 kali untuk mencegah dan mendeteksi dini adanya permasalahan selama kehamilan (Sulistyawati, 2019).

Kecemasan pada ibu hamil dapat dipengaruhi karena tidak melakukan pemeriksaan ANC. Pemeriksaan ANC yang dilakukan oleh ibu dapat membantu mengendalikan rasa cemas yang muncul saat kehamilannya, salah satu upaya yang dilakukan tenaga kesehatan untuk menurunkan angka kecemasan pada ibu hamil yaitu pendidikan kesehatan pada saat ANC sehingga Ibu hamil dapat terhindar dari resiko resiko buruk akibat kehamilan dengan cara melakukan pengawasan dengan baik terhadap kehamilannya dengan melakukan Pemeriksaan ANC. Pemeriksaan ANC akan meningkatkan pemahaman ibu tentang kehamilan dan mampu mengurangi kecemasan dalam menghadapi proses persalinan (Komariyah, 2014). Apalagi kondisi kesehatan 
dunia sekarang ini yang sedang dilanda pandemi COVID-19, membuat ibu semakin cemas dengan keadaan lingkungannya.

Ibu hamil tercatat salah satu kelompok rentan resiko terinfeksi COVID-19 dikarenakan pada masa kehamilan terjadinya perubahan fisiologi yang mengakibatkan penurunan kekebalan parsial. Dimasa pandemi COVID-19 ibu hamil merasa semakin cemas dikarenakan cara penyebaran virus ini, yaitu melalui droplet pada saat bersin, batuk atau berbicara. Droplet dapat menempel pada benda dan permukaan seperti meja, gagang pintu, dll. Seseorang dapat terinfeksi oleh virus ini apabila menyentuh benda atau permukaan benda tersebut yang kemudian menyentuh mata, hidung dan mulut tanpa mencuci tangan. Untuk mengurangi rasa cemas ibu dapat diatasi dengan terapi Hypno prenatal dan prenatal message pada ibu hamil (Susilowati, 2019).

Hypno prenatal merupakan suatu kegiatan yang dapat membantu seseorang menjadi rileks dan tenang, dimana efek dari kondisi ini akan berpengaruh terhadap ibu dan lingkungannya. Teknik Hypno prenatal merupakan suatu tindakan eksternal yang dapat mempengaruhi respon internal individu. Teknik Hypno prenatal adalah salah satu teknik relaksasi yang bersumber dari diri sendiri berupa kata-kata atau kalimat pendek ataupun pikiran yang bisa membuat pikiran tentram. Hypno prenatal dilakukan dengan membayangkan diri sendiri berada dalam keadaan damai dan tenang, berfokus pada pengaturan nafas dan detakan jantung (Farada, 2011).

Selain Hypno prenatal, dalam perawatan ibu hamil di Indonesia terdapat praktek budaya yang banyak dilakukan salah satunya adalah pijat tradisional (massage) pada ibu hamil. Prenatal massage dapat menjadi penting dan menguntungkan karena diketahui dapat meningkatkan relaksasi, mengurangi nyeri dan stres, dan sangat banyak manfaat kesehatan yang lain. Massase atau pijatan telah diketahui mempunyai banyak manfaat untuk kesehatan. Prenatal massase yang dilakukan dengan teknik yang tepat selama masa kehamilan dapat menurunkan kecemasan dan depresi, karena tingkat kortisol (hormon stres) menurun dalam tubuh, meringankan nyeri pada kaki, punggung, otot, dan sendi, meningkatkan aliran oksigen pada jaringan dan otot dan memperbaiki suasana hati dan meningkatkan rasa bahagia, karena meningkatnya hormon serotonin dan dopamine (Ibrahim, 2018).

Berdasarkan Profil Kesehatan Kota Padang Tahun 2019 tentang cakupan pelayanan kesehatan kunjungan ibu hamil di Puskesmas Nanggalo cakupannya tidak sampai 100\%. Klinik MERCUBAKTIJAYA Padang berada di dalam wilayah kerja Puskesmas Nanggalo. Hasil wawancara yang penulis lakukan dengan ibu hamil pada bulan November 2020 di Klinik MERCUBAKTIJAYA Padang didapatkan bahwa dari 3 orang ibu hamil yang datang berkunjung mengalami kecemasan 100\% selama kehamilan. Berdasarkan fenomena tersebut penulis tertarik untuk memberikan terapi Hypno prenatal dan Prenatal Message untuk mengurangi kecemasan pada ibu hamil dimasa pandemi COVID-19 di Klinik MERCUBAKTIJAYA Padang. 


\section{Metode Pelaksanaan}

Kegiatan abdimas ini dilaksanakan pada hari Rabu tanggal 16 Desember 2020 di Klinik MERCUBAKTIJAYA Wilayah Kerja Puskesmas Puskesmas Nanggalo Padang. Sasaran dari kegiatan abdimas ini adalah ibu hamil. Tahapan-tahapan kegiatan yang dilakukan adalah :

1. Sebelum melakukan penyuluhan, pengabdi melakukan pemeriksaan berat badan ibu hamil dan pemeriksaan Antenatal Care (ANC) atau kehamilan,

2. Pengabdi melakukan pre-test tentang rasa cemas yang dialami oleh ibu hamil

3. Pengabdi juga melakukan pre-test terkait pengetahuan ibu hamil tentang hypno prenatal dan prenatal message

4. Pengabdi menyampaikan materi tentang hypno prenatal dan prenatal message pada ibu hamil

5. Pengabdi melakukan pemberian terapi hypno prenatal dan prenatal massage pada ibu hamil

6. Pengabdi melakukan post-test kepada ibu hamil tentang materi yang sudah disampaikan dan perasaan cemas yang dialami ibu hamil.

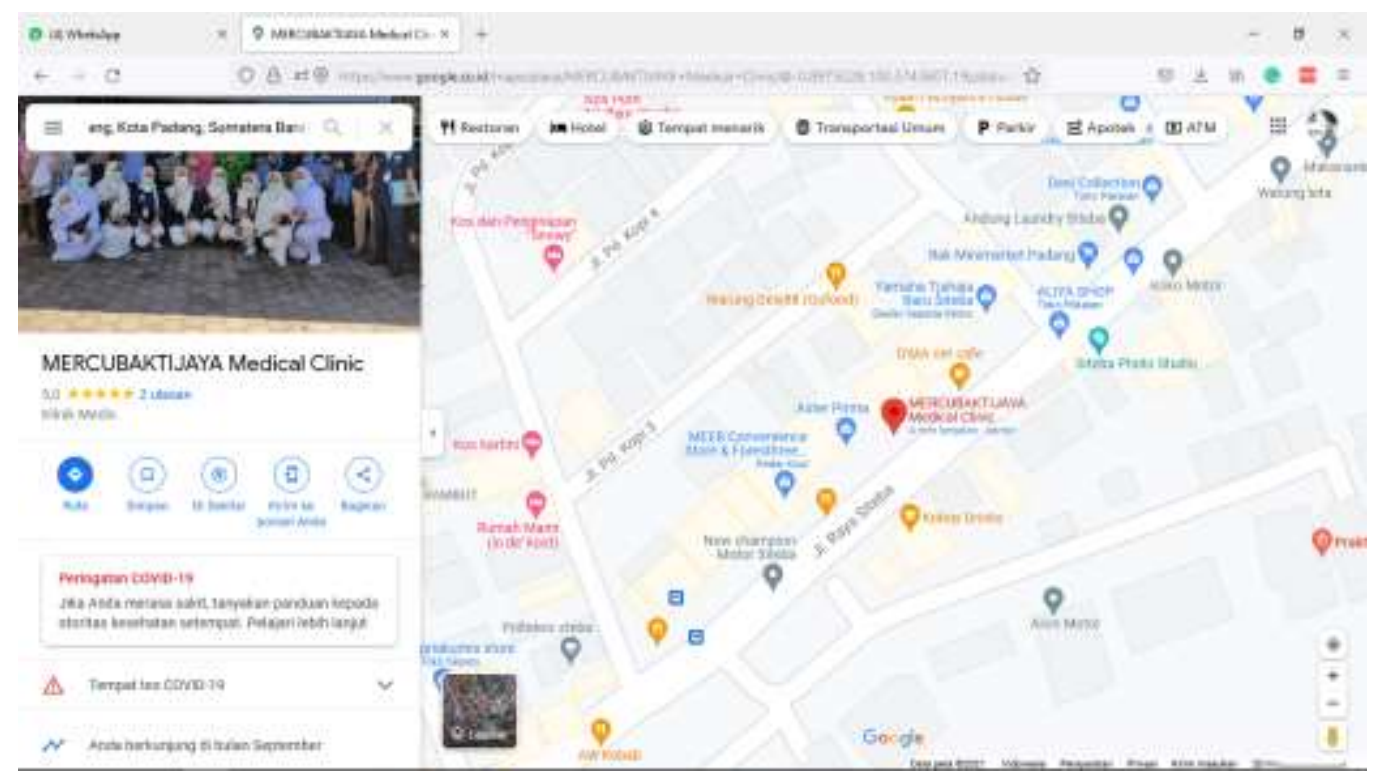

Gambar 1. Peta Wilayah Sasaran

\section{Hasil}

Kegiatan pengabdian kepada masyarakat ini dihadiri oleh 3 orang ibu hamil. Target utama dari pelaksanaan kegiatan pengabdian kepada masyarakat ini adalah ibu hamil dapat mengetahui dan merasakan pengalaman tentang terapi hypno prenatal dan prenatal massage serta dapat menurunkan perasaan cemas yang dialami oleh ibu hamil.

Adapun hasil kegiatan abdimas yang sudah dilakukan adalah sebagai berikut

1. $100 \%$ kondisi kehamilan ibu hamil dalam keadaan baik dan sehat

2. $100 \%$ ibu hamil dapat memahami dan mengerti tentang hypno prenatal dan prenatal massage

3. $100 \%$ perasaan cemas yang dialami pada ibu hamil mengalami penurunan. 


\section{Jurnal ABDI MERCUSUAR}

Vol. 01, No. 02 Desember, 2021, pp. 045- 051
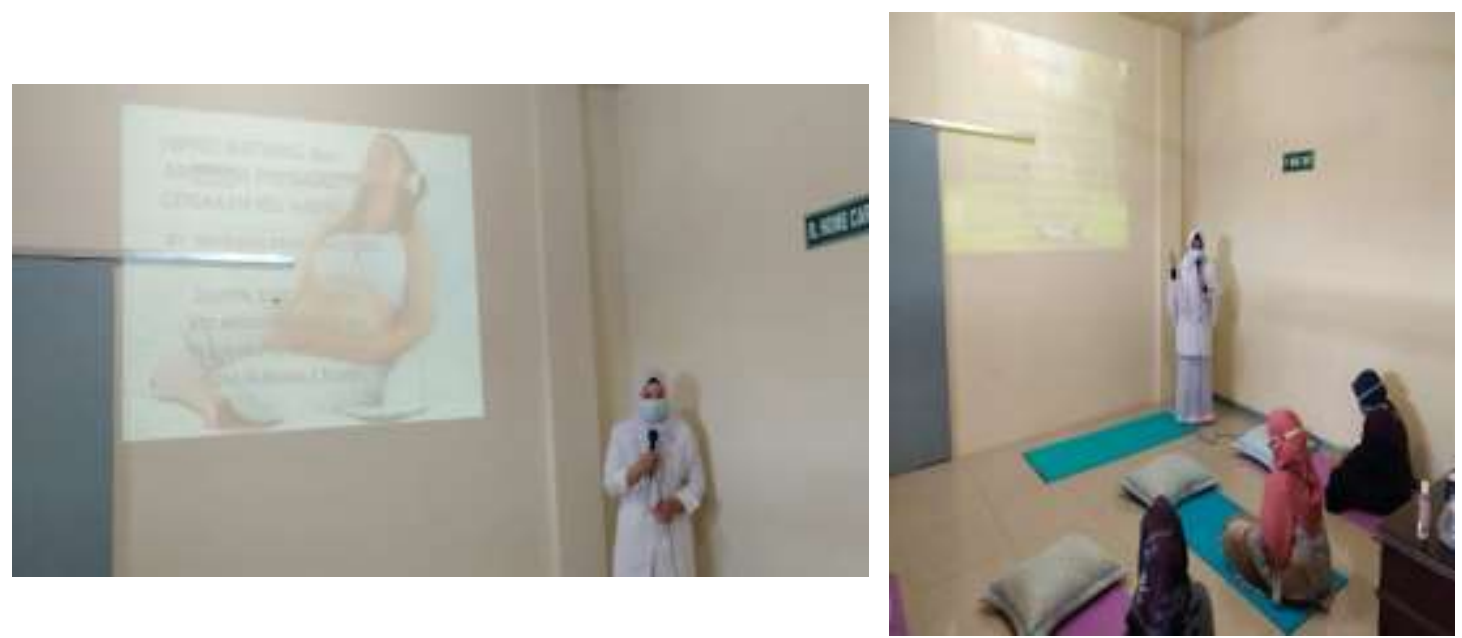

Gambar 2. Pemberian Penyuluhan tentang Hypno prenatal dan message prenatal
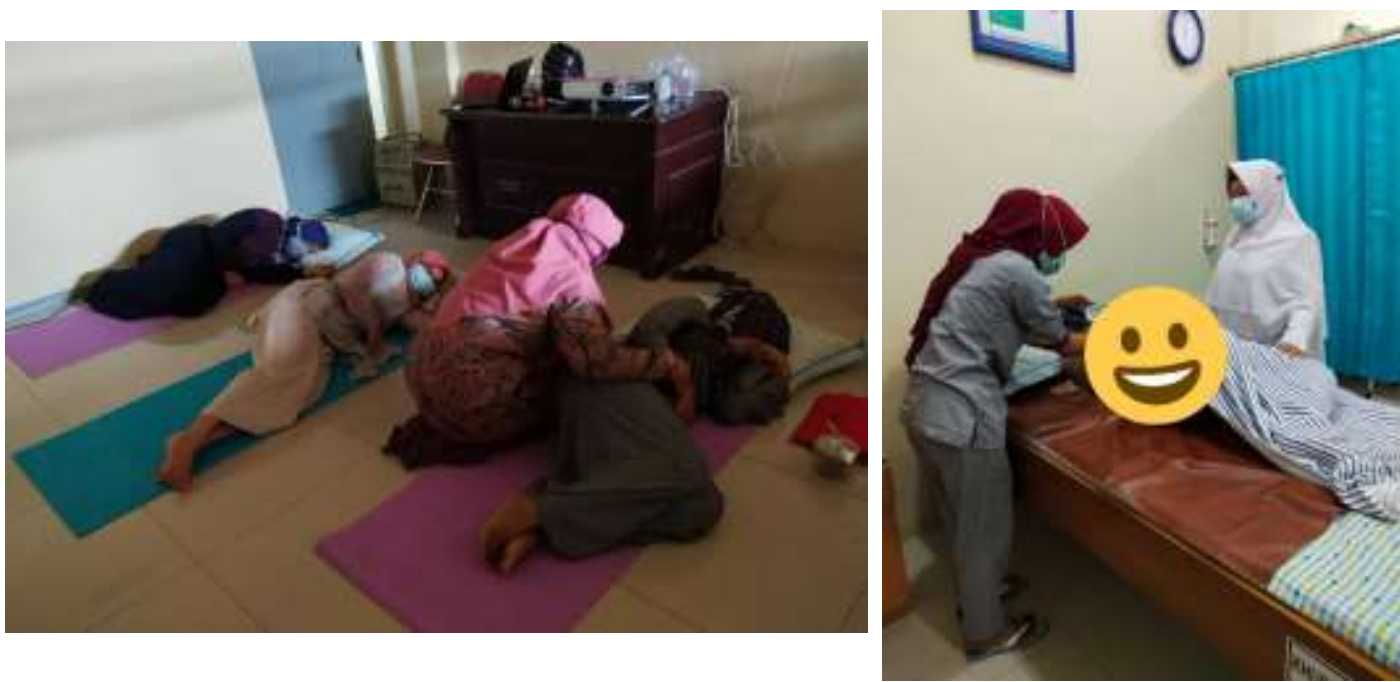

Gambar 3. Pemberian Terapi Hypno prenatal dan prenatal message

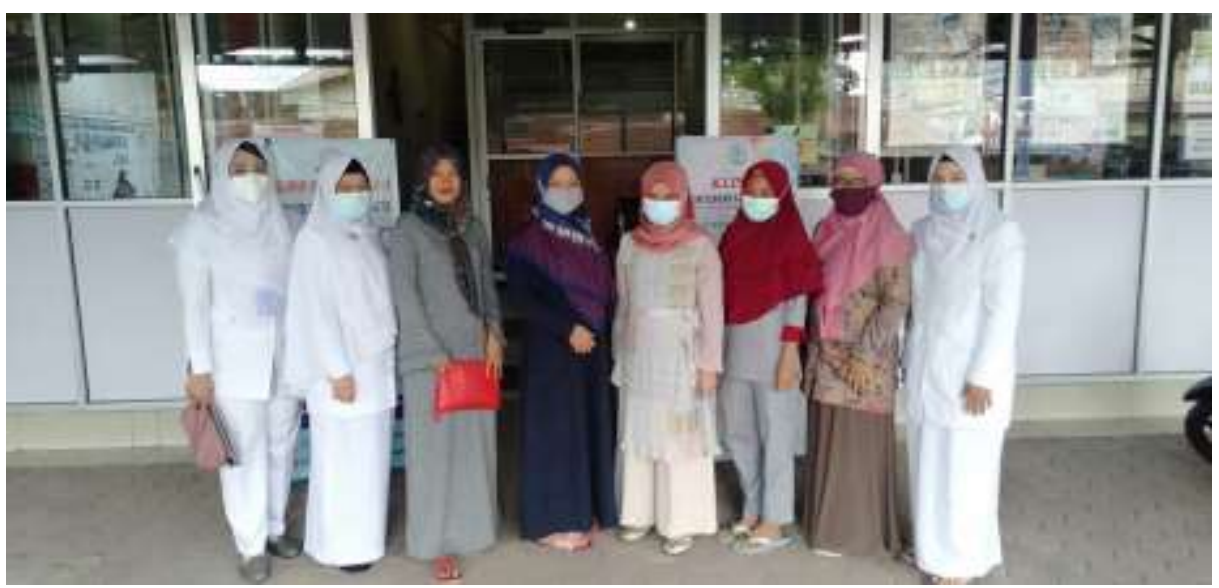

Gambar 4. Dokumentasi bersama ibu hamil 


\section{Diskusi}

Ibu hamil merupakan salah satu kelompok yang rentan terinfeksi COVID-19. Oleh karena itu ibu hamil mudah mengalami kecemasan. Kecemasan itu dapat terjadi karena perubahan peningkatan hormone kehamilan serta kondisi kehamilan sendiri seringkali menimbulkan rasa tidak nyaman selama kehamilan yang menjadi pencetus paling besar pengaruhnya terhadap kecemasan (Beatrix, 2015)

Penanganan pertama yang dapat diberikan pada ibu hamil yang mengalami kecemasan saat menjelang persalinan adalah dengan memberikan terapi nonfarmakologi seperti teknik hypno prenatal. Teknik hypno prenatal merupakan suatu tindakan eksternal yang dapat mempengaruhi respon internal individu. Teknik hypno prenatal adalah salah satu teknik relaksasi yang bersumber dari diri sendiri berupa kata-kata atau kalimat pendek ataupun pikiran yang bisa membuat pikiran tentram. Relaksasi hypno prenatal dilakukan dengan membayangkan diri sendiri berada dalam keadaan damai dan tenang, berfokus pada pengaturan nafas dan detakan jantung. Ibu primigravida yang mengalami cemas akan timbul respon fisiologis berupa peningkatan denyut jantung, sehingga dapat meningkatkan curah jantung yang dapat menyebabkan preeklamsi. Respon tersebut dapat dikurangi dengan ibu hamil melakukan teknik hypno prenatal yang akan menciptakan respon relaksasi dari latihan nafas dalam dan latihan konsentrasi. Respon hypno prenatal tersebut akan merangsang peningkatan kerja saraf parasimpatis yang akan menghambat kerja dari saraf simpatis, sehingga hormon penyebab cemas dapat berkurang. Tujuan utama hypno prenatal adalah membawa pikiran ke dalam kondisi mental yang optimal (Farada, 2011)

Dewasa ini banyak metode yang membantu menurunkan kecemasan pada ibu hamil, nifas dan menyusui, baik metode farmakologis (menggunakan obat-obatan) maupun nonfarmakologi. Tindakan nonfarmakologis dalam menurunkan kecemasan merupakan trend baru yang dapat dikembangkan. Metode nonfarmakologi selanjutnya adalah prenatal massage (Susilowati, 2019).

Manfaat prenatal massage yang utama adalah mengurangi stress, pijat kehamilan mempunyai efek mendalam pada fisiologis wanita hamil, atau somatic dan reaksi emosional terhadap stress. Relaksasi yang diberikan oleh terapi prenatal massage lebih ditujukan untuk mengurangi rasa sakit dan memberikan efek analgesic. Pelepasan histamine dan stimulasi lokal membuat pembuluh darah menjadi membesar, mengeluarkan produk-produk limbah dan racun yang akan diserap, jaringan banyak mengandung oksigen dan nyeri berkurang. Selama prenatal massage mengeluarkan Beta-endorfin dan serotonin neurotransmitter dan bekerja bersama-sama untuk menghambat system syaraf pusat dan menghasilkan badan lebih santai. Prenatal massage dapat membuat ibu hamil menjadi lebih rileks dan senang, karena dengan dilakukan prenatal message akan memperlancar sirkulasi darah ibu, sehingga hal tersebut juga bisa mengurangi rasa kecemasan ibu di dalam kehamilan (Stillerman, 2008). 


\section{Kesimpulan dan Saran}

Kegiatan pengabdian kepada masyarakat ini dilaksanakan dengan menggunakan memberikan pendidikan kesehatan kepada ibu hamil dan pemberian terapi hypno prenatal dan prenatal massage. Setelah diberikan terapi terdapat $100 \%$ penurunan rasa cemas yang dialami oleh ibu hamil. Disarankan kepada tim pengabdi selanjutnya untuk melakukan terapi hypnobirhting dan massage pada ibu bersalin, nifas dan menyusui.

\section{Ucapan Terima Kasih}

Penulis mengucapkan terimakasih kepada ketua LP2M STIKes MERCUBAKTIJAYA Padang yang telah memberikan izin untuk terlaksananya kegiatan pengabdian masyarakat ini, dan juga terima kasih kepada Kepala Klinik MERCUBAKTIJAYA Padang atas izin, dukungan dan kerjasamanya dalam terlaksananya kegiatan pengabdian masyarakat ini. Serta semua pihak yang membantu lancarnya kegiatan pemberian terapi hypno prenatal dan prenatal massage pada ibu hamil.

\section{Daftar Referensi}

Beatrix, Sofie. 2015. Cerita Kehamilan Shireen Sungkar. Jakarta: Kawan Pustaka

Ibrahim, E. A dan Asiah N, N. 2018. Message Postpartum dan Statu Fungsional Ibu Pasca Salin di Medan. Buletin Farmatera. Page 24-32

Komariyah. 2014. Hubungan Antara Dukungan Keluarga dengan Kepatuhan Ibu Hamil dalam Pemeriksaan Antenatal Care. http://perpusnwu.web.id/3628

Farada, R.A. 2011. Pengaruh Teknik Relaksasi Terhadap Tingkat Kecemasan Pada Ibu Primigravida Trimester III di Wilayah Kerja Puskesmas Kotakulon Kabupaten Bondowoso. Universitas Jember. Page 75

Stillerman, Elaine. 2008. Prenatal Message, A Textbook of Pregnancy, Labor, and Postpartum Bodywork. New York: Mosby Elsevier

Sulistyawati, A. 2019. Asuhan Kebidanan pada Masa Kehamilan. Jakarta: Salemba Medika

Susilowati,T., Pramana N, dan Muis, S.F. 2019. Intervensi Non Farmakologi Terhadap Kecemasan Pada Primigravida. Jurnal Ilmiah Permas. Page181-186 